\title{
PENGARUH PENGGUNAAN BLENDED LEARNING BERBASIS SCHOOLOGY TERHADAP HASIL BELAJAR PESERTA DIDIK PADA MATERI HIDROLISIS GARAM
}

\author{
Suci Pratiwi ${ }^{1}$, Lazulva ${ }^{2}$ \\ Program Studi Pendidikan Kimia, Fakultas Tarbiyah dan Keguruan, Pekanbaru \\ Universitas Islam Negeri Sultan Syari Kasim Riau \\ *Email: ${ }^{*}$ lazulva@uin-suska.ac.id
}

\begin{abstract}
Abstrak
Penelitian ini bertujuan untuk menaikkan hasil belajar materi kesetimbangan ion serta $\mathrm{pH}$ larutan garam peserta didik dalam mempergunakan model pembelajaran blended learning dengan basis schoology. Metode yang dipergunakan yaitu metode kuantitatif dari jenis penelitian quasi experimental deign. Populasi yang diambil peneliti ini yaitu keseluruhan siswa kelas XI IPA SMAN 1 Tapung Hilir dari kelas XI Tahun Ajaran 2018/ 2019 serta sampelnya yaitu siswa kelas XI IPA 1 yang menjadi kelas eksperimen dan XI IPA 2 menjadi kelas kontrol. Desain penelitian yang pakai yaitu pretest-posttest control group design. Dalam mengambil sampel penelitian mempergunakan teknik acak kelas. Analisis data lewat memakai anova satu jalur (one way anova). Dalm menghitung data dianalisis mempergunakan statistika inferensial lewat bantuan aplikasi sofware SPSS 16.0. Hasil dalam menghitung data penelitian didapat bahwa nilai sig $<\alpha$, yang mana nilai signifikannya sebanyak dari tingkat siginifikan kurang dari 0,05 yakni sejumlah 0,003. Memperlihatkan bahwa rata-rata hasil belajar materi kesetimbangan ion serta ph larutan garam naik melewati proses belajar mengajar blended learning dengan basis schoology. Sehingga bisa diambil kesimpulan bahwa ada pengaruh pembelajaran blended learning dengan basis schoology pada kenaikan hasil belajar materi kesetimbangan ion serta ph larutan garam peserta didik.
\end{abstract}

Kata Kunci : Blended learning, Schoology, dan Hasil Belajar Materi Kesetimbangan lon Dan pH Larutan Garam.

\section{Abstract}

This research aimed at increasing student learning achievement on lon and $\mathrm{pH}$ Saline Solution Equilibrium lesson by using Schoology blanded Learninglearning model. Qualitative method was used in this research with quasi- experimental research design. All the eleventh-grade students of Natural Science of State Senior High School 1 TapungHilir in the Academic Year of 2018/2019 were the population of this research, and the samples were the eleventh-grade students of Natural Science 1 as the experimental group and the students of Natural Science 2 as the control group. Pretestposttest control group design was used in this research. Sampling was done by using random technique. Analyzing the data was using one-way ANOVA. The data were analyzed by using inferential statistic with the help of SPSS 16.0 software. The results of calculating the data showed that the score of Sig. was lower than $\alpha$, the significance score was 0.003. It showed that the learning achievement mean on Ion and $\mathrm{pH}$ Saline Solution Equilibrium lesson was increasing through the use of Schoology based Blended Learning. It could be concluded that there was an effect of using Schoology- based Blended Learning toward student learning achievement on lon and $\mathrm{pH}$ Saline Solution Equilibrium lesson.

Keywords: Blended Learning, Schoology, Learning Achievement, Ion and pH Saline Solution Equilibrium 


\section{Pendahuluan}

Perkembangan IPTEK makin mendukung majunya pembaharuan dalam memanfaatkan hasil teknologi serta mekanisme pembelajaran. Tumbuh kembang teknologi informasi dan komunikasi (TIK) ini sangat mempunyai dampak di berbagai bidang termasuk bidang pendidikan. Pendidikan ialah kesadaran guna mengembangkan kemapuan SDM melewati aktivitas pembelajaran. Berdasarkan Rencana Strategis Kementrian Pendidikan dan Kebudayaan (Kemdikbud) selama 2010-2014, salah satu arah kebijakan pembangunan pendidikan nasional adalah penguatan serta memperluas manfaat dari TIK dibidang pendidikan. TIK yaitu teknologi yang dipakai guna mengkomunikasikan dan merancang, memproses serta menyebarkan informasi.Salah satu contoh perangkat TIK diantaranya perangkat audiovisual, radio, televisi, telepon, internet, serta komputer. Pembelajaran berbasis TIK secara konseptual menurut Kemdiknas adalah "Pembelajaran tatap muka didukung dari adanya terdapatnya fasilitas teknologi informasi dan komunikasi (TIK) yang menunjang pendidik sebagai penyedia materi dan pembimbing menggunakan konten digital".

Diterapkannya kurikulum 2013 dan perkembangan TIK yang berkembang sangat pesat di segala bidang keberlangsungan hidup, diantaranya bidang pendidikan. Perkembangan TIK telah memajukan perubahan yang sangat pesat di bidang pendidikan.

Diantara permasalahan yang sering timbul pada proses pembelajaran yaitu aktivitas pembelajaran yang kurang membuat tertarik, cenderung pasif, malu serta takut untuk mengajukan pendapatnya dan tidak mempunyai keberanian menjelaskannya. Mereka lebih pendiam bila terdapat sesuatu yang tidak mereka mengerti daripada yang mereka tanyakan kepada guru. Jumlah peserta didik yang cenderung banyak dapat menurunkan mutu interaksi antara guru dengan peserta didik, maka dari itu pencapaian hasil kurang menjadi kurang optimal.

Mengacu pada observasi awal yang sudah dilaksanakan di SMAN 1 Tapung Hilir, kurikulum yang dipakai sekarang ini yaitu kurikulum 2013, dimana kurikulum tersebut guru tidak menjadi teacher centered dan siswa dituntut aktif dalam proses belajar mengajar. Namun pada kenyataannya siswa belum bisa berperan aktif dalam proses pengajaran. Disamping itu, peserta didik malu untuk bertanya langsung kepada guru didalam kelas. Disisi lain terdapat sarana komputer tidak dipakai 
menjadi media dalam proses pengajaran serta menjadi sumber informasi bagi siswa. Kemudian Hasil belajar peserta didik masih kurang maksimal sebab tetap mempergunakan model pembelajaran tradisional untuk menyampaikan materi pembelajaran selama proses belajar mengajar. Hal demikian memperlihatkan bahwa berhasilnya proses pembelajaran masih kurang merasa puas, sebab masih terdapat peserta didik yang hasilnya masih di bawah (KKM), dan standar integritas minimal (KKM) sekolah untuk mata pelajaran kimia. 75. Mata pelajaran kimia sering dianggap menjadi topik yang sukar sebab kimia adalah materi abstrak. Mayoritas ilmu kimia adalah ilmu eksperimental serta mayoritas pengetahuannya berasal dari penelitian laboratorium (Chang, 2004)

Belajar kimia intinya berasal dari kebenaran sesungguhnya yang ditemukan dari konsep mikroskopik serta submikroskopik yang selanjutnya dilambangkan. Jadi, peserta didik cenderung lebih mengerti konsep mikroskopis serta submikroskopis. Oleh karena itu, sangat penting untuk mengembangkan sarana media pendidikan yang bisa memberi pengalaman yang komprehensif dari konsep faktual (makroskopis) hingga abstrak (mikroskopis dan mikroskopis). Diantara materi pembelajaran kimia yaitu kesetimbangan ion serta $\mathrm{pH}$ larutan garam.

Dengan merespons permasalahan yang berkaitan dengan kondisi pembelajaran dan hasil belajar siswa yang rendah sehingga butuh dilakukan perencanaan ulang terkait proses belajar mengajar. Jalan keluar yang bisa memecahkan masalah dalam pelajaran kimia yaitu guru melaksanakan perbaikan dalam proses pengajaran serta mempergunakan metode atau model secara tepat untuk melibatkan siswa dalam proses belajar mengajar serta mengaktifkan antara peserta didik dengan guru. Diantara model pengajaran yang akan diaplikasikan yaitu model pembelajaran blended learning berbasis Schoology.

Blended learning ialah kombinasi pengajaran langsung dengan online atau e-learning. sehingga demikian, blended learning ini mempunyai tujuan guna memadukan karakteristik model belajar mengajar dengan basis internet yakni efisiensi waktu, biaya rendah serta kemudahan siswa dalam melakukan akses bahan ajar setiap saat. Selanjutnya ada model pembelajaran tatap muka yang melekat ataupun model pembelajaran konvensional yang menolong siswa mempelajari materi pembelajaran yang baru diajarkan dan melakukan interaksi dengan peserta didik dan guru lain di kelas. Belajar mengajar terpadu dapat secara dinamis mentransfer prinsip pembelajaran dari pusat pengajaran ke pusat 
siswa. Pembelajaran campuran melengkapi kekurangan dari tatap muka dan pembelajaran elektronik (Siswa, 2019).

Banyak sekali media pendidikan online yang telah dikembangkan untuk siswa seperti pelajaran kimia salah satunya adalah schoology. Schoology adalah sistem manajemen pembelajaran sosial (LMS) yang melakukan penawaran pengajaran gratis serta memudakan untuk dipergunakan. Schoology mempunyai spesifikasi yang lebih akurat serta sistematis daripada bentuk LMS lainnya. Schoology sangat akurat serta sistematis dengan keseluruhan alat pembelajaran yang berfungsi seperti di dunia sesungguhnya, diawali dari pemeriksaan kehadiran, kuis, tes, sampai saat mengumpulkan makalah siswa. Schoology sangat mungkin dipergunakan segala macam data seseorang, kelompok serta diskusi kelas untuk bekerja sama, membuat schoology sangat cocok untuk digunakan menjadi media pendidikan tambahan lewat mempergunakan model blended learning (KARTIKA MURNI, 2016).

Disamping itu, menurut penelitian dari Muh Yusuf Hidayat, dkk menyatakan bahwa model pembelajaran hybrid dengan basis schoology lebih efisien dalam hal hasil pencapaian pembelajaran siswa. Hasil penelitian memperlihatkan bahwa kelas eksperimen termasuk dikategorikan tinggi dari rata-rata nilai siswa 86,17, serta kelas kontrol berada di kelas menengah dengan nilai rata-rata 78,06 (Hidayat \& Andira, 2019). Auliyah Dzakiyyah, dkk juga menyimpulkan bahwa penggunaan $E$ Learning dengan basis Schoology lewat blended learning bisa menaikan hasil pengajaran kognitif siswa dan hasil $\mathrm{N}$-gain sebesar 0,65 (Dzakiyyah et al., 2018).

\section{Metode}

Metode penelitian yang dipergunakan oleh peneliti yaitu quasi experimental dan desain pretest-posttest control group design. Desain demikian ada 2 kelompok yang dapat ditentukan dengan acak, dan lalu dilakukan pre-test guna melihat apakah terdapat perbedaan diantara kelompok eksperimen dengan kelompok control (Sugiyono, 2011). Kelas eksperimen dberikan perlakuan menggunakan Blended Learning berbasis Schoology, sebaliknya kelas kontrol memakai media LKPD. Kedua kelas lebih dulu dibagikan pretest, sesudah dijalankan perlakukan kemudian diberikan posttest. Soal yang dipergunakan dalam pretest serta posttest adalah sama dan pada waktu yang serupa. 
Penelitian ini dijalankan di SMAN 1 Tapung Hilir pada kelas XI Tahun Ajaran 2018/ 2019. Populasi yang diambil peneliti yaitu siswa kelas XI MIA SMAN 1 Tapung Hilir dengan jumlah 3 kelas. Tiap kelas mempunyai jumlah 35 peserta didik.

Penelitian ini mengambil 2 kelas yang dijadikan sampel dengan menggunakan teknik cluster random sampling guna menetapkan sampel, bila sumber data yang diuji sangat luas. Sebaliknya sampel yang diteliti oleh peneliti yaitu peserta didik XI SMAN 1 Tapung Hilir yang terbagi menjadi 2 kelas yang memiliki kemampuan homogen sesudah dilaksanakan pengujian homogenitas.

Teknik dalam mengumpulkan data yang dipergunakan oleh peneliti ini meliputi tes, observasi, dan dokumentasi. Pengujian yang dipakai oleh peneliti yaitu (a) pengujian homogenitas yang dibagikan sebelum penelitian. Tes ini dilaksanakan guna memeriksa kemiripan potensi kedua kelas yang dijadikan sampel. Untuk pengujian homogenitas, peneliti mempergunakan nilai ulangan harian dari guru mata pelajaran, (b) Pretest, yang dilakukan sebelum dimulainya penelitian. Hasil tes awal dipakai sebagai nilai tes awal, (c) posttest, dibagikan sesudah penelitian berakhir guna mendapatkan kemampuan kognitif peserta didik setelah melakukan penggunaan Blended Learning berbasis Schoology. Hasil dari tes ini dipergunakan menjadi nilai posttest. Soal yang dibagikan merupakan soal yang serupa ketika dilakukannya pretest. Sedangkan Pengamatan pada penelitian ini diartikan guna mengetahui dengan langsung proses pengajaran yang dilaksanakan, termasuk sistem pembelajaran serta metode yang diterapkan terhadap kemampuan kognitif siswa, pada saat pembelajaran dilakukan, dan dokumentasi digunakan untuk melengkapi dokumentasi selama penelitian, dan dokumen-dokumen yang berkaitan dengan peserta didik kelas XI di SMA Negeri 1 Tapung Hilir.

Teknik analisis data yang diambil peneliti, yakni, dilakukan pengarahan guna menanggapi rumusan permasalahan ataupun menguji hipotesis. Sebab datanya bersifat kualitatif dan kuantitatif, metode analisis datanya mempergunakan metode deskriptif serta statistik. Metode penggambaran data kuantitatif dan kualitatif bisa menggunakan teknik statistik deskriptif. Statistika deskriptif yaitu statistik yang dipakai guna menganalisa data yang sudah dikumpulkan seperti halnya apa adanya tanpa bermaksudkan untuk menyusun generalisasi hasil penelitian.

Validitas tes yang dipergunakan oleh peneliti yaitu validitas isi (content validity) dan empiris, reliabilitas tes, daya pembeda soal, serta tingkat kesulitan soal. 
Sebaliknya untuk analisis data penelitian yang dipakai berupa analisa data awal (uji homogenitas), uji normalitas, serta analisis data akhir (uji hipotesis).

Dalam penelitian ini homogenitas populasi dilakukan pengujian dengan menguji data dari hasil tes sebelumnya dengan uji F. Dalam penelitian kali ini dilaksanakan pengujian homogenitas dalam data pre-test dan post-test dari kedua eksperimen dengan kelompok kontrol. Sedangkan pengujian normalitas dilaksanakan guna melihat apakah sebaran data normal atau tidak. Hal demikian krusial diketahui mengenai regulasi yang mengatur pemilihan pengujian statistik yang akan dipergunakan. Uji normalitas bisa dijalankan lewat pengujian Chi Kuadrat $\left(\mathrm{X}_{2}\right)$, Liliefors atau Kolmogorovsmirnov. Metode yang dipakai oleh peneliti yaitu pengujian Shapiro Wilk (S-W) dengan memanfaatkan program SPSS 20.0. Hitung $\geq 0,05$ (sig.acuan), maka distribusi skornya normal, demikian pula sebaliknya, kemudian tahap seterusnya yaitu melaksanakan pengujian homogenitas agar uji "T" dapat dilanjutkan. Bila distribusi data tidak normal sehingga direkomendasikan guna mempergunakan pengujian nonparametik. Teknik analisis data yang dipakai oleh peneliti ini yaitu menganalisis data melalui mempergunakan uji " $T$ ". Rumus ttest yang dipergunakan yaitu:

\section{Sample Related}

$$
\mathrm{t}=\frac{M_{x}-M_{y}}{\sqrt{\frac{\sum x^{2}+\sum y^{2}}{N_{x}+N_{y}-2}\left(\frac{1}{N_{x}}+\frac{1}{N_{y}}\right)}}
$$

Keterangan:

$M=$ Nilai rata-rata hasil per kelompok

$\mathrm{N}=$ Banyaknya Subjek

$\mathrm{x}=$ Deviasi setiap nilai $\mathrm{x}_{2}$ dan $\mathrm{x}_{1}$

$y=$ Deviasi setiap nilai $y_{2}$ dari mean $y_{1}$ (Suharsimi, 2010)

Pengujian : Hipotesis diterima $t_{\text {hitung }} \geq t$ tabel dari derajat nilai $\alpha=0,05$.

$\mathrm{t}$ hitung $\geq \mathrm{t}$ tabel maksudnya $\mathrm{H}_{0}$ ditolak

$\mathrm{t}$ hitung $\leq \mathrm{t}$ tabel maksudnya но diterima. 


\section{Hasil dan Pembahasan}

Dalam penelitian ini, dipilih dua sampel dengan kapasitas yang sama (homogen). Maka dilakukanlah pengujian homogenitas pada populasi yakni kelas XI IPA 1, XI IPA 2, serta XI IPA 3. Untuk mengetahui apakah ketiga kelas tersebut homogen, peneliti mempergunakan nilai ulangan harian dari guru mata pelajaran. Nilai ulangan harian tersebut kemudian dianalisis uji varians homogenitas dengan bantuan menggunakan SPSS 21. Berdasarkan hasil analisis uji homogenitas itu memperlihatkan bahwa hasil pengujian homogenitas yang dilaksanakan melalui uji-F memperlihatkan bahwa data $F$ hitung $(1,243)<$ Ftabel $(3,99)$ dengan $d f 1=2$ dan $d f 2=98$ dari taraf signifikansi $5 \%$, sehingga bisa diambil kesimpulan bahwa variansvarians kedua kelas adalah homogen dimana Fhitung < Ftabel. Hal demikian memperlihatkan bahwa kelas XI IPA 1, XI IPA 2, serta XI IPA 3 ialah homogen. Sebab variansnya homogen, sehingga bisa diambil kesimpulan bahwa dari tiga kelas itu mempunyai kemampuan yang homogen serta bisa dijadikan sebagai sampel penelitian. Maka dari itu saat mengambil sampel mempergunakan teknik random sampling dengan terpilih IPA kelas XI 1 yang menjadi kelas eksperimen menggunakan Blended Learning Berbasis Schoology dan kelas XI IPA 2 yang menjadi kelas kontrol mempergunakan model pembelajaran tanpa Blended Learning Berbasis Schoology.

Sebelum penelitian dilaksanakan, peneliti telah membuat instrumen penelitian, instrumen tersebut terlebih dahulu harus diuji kelayakannya sebelum diujikan. Untuk melihat kelayakan soal yang akan diujikan berupa soal pretest dan posttest tersebut, soal diujikan lebih dulu pada kelas yang sudah memelajari materi yang akan diteliti. Hal demikian guna mengetahui kualifikasi validitas, reliabilitas, tingkat kesulitan soal serta daya pembeda soal. Pengujian dilakukan dikelas XII SMAN 1 Tapung Hilir sejumlah 30 siswa, soal yang diujikan berjumlah 30 soal pilihan ganda. Dalam menghitung validitas empiris soal dilakukan dengan memakai bantuan komputer program ANATES Ver. 4.0.5., maka didapat 27 butir soal secara valid dan 3 butir soal yang tidak valid dari 30 soal. 


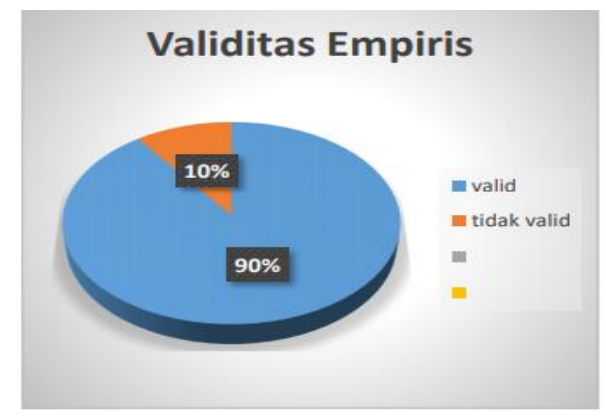

Gambar 1. Diagram Kevalidan Soal

Berdasarkan hasil uji coba soal yang dilaksanakan melalui memakai bantuan komputer program ANATES Ver. 4.0.5, didapat reliabilitas tes hasil belajar kognitif sebanyak 0.94 dinyatakan kriteria kuat. Sedangkan berdasarkan tingkat kesulitan soal diperoleh hasil bahwa diantara 30 soal yang sudah diujikan $87 \%$ dengan kategori sedang dan 13\% dengan kategori mudah. Berdasarkan ke 30 soal tersebut, maka dipilih 20 soal yang akan dijadikan sebagai instrumen penelitian yakni dari kualifikasi sedang dan mudah. Tingkat kesukaran soal disajikan pada Gambar 2.

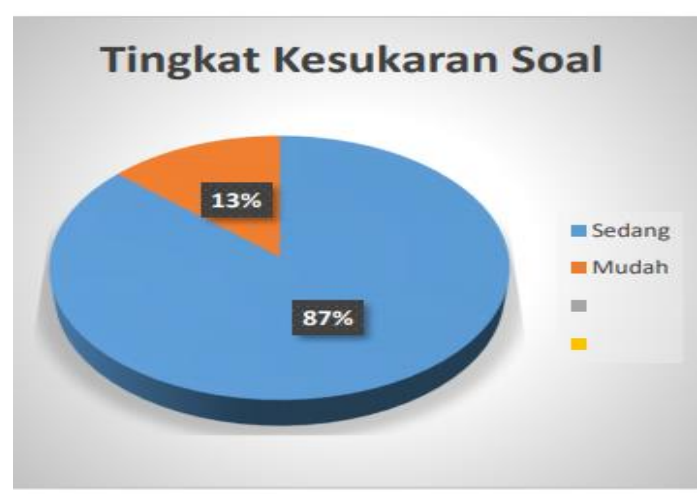

Gambar 2. Diagram Tingkat Kesukaran Soal

Mengacu pada hasil analisis uji coba untuk daya pembeda soal, dilihat $3 \%$ soal dari kualifikasi sangat jelek, 3\% soal dari kualifikasi jelek, 17\% soal dari kualifikasi cukup, $27 \%$ soal dari kualifikasi baik, serta $50 \%$ soal dari kriteria sangat baik. 


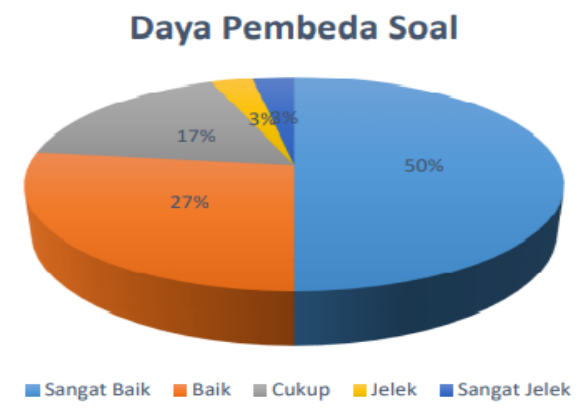

Gambar 3. Diagram Daya Pembeda Soal

Selanjutnya adalah dilakukan tes (berupa pretest dan posttest) untuk kedua kelas dengan perlakuan yang berbeda tersebut. Diperolehnya data nilai pretest serta posttest diantara kelas eksperimen dengan kelas kontrol, bisa dijadikan untuk melihat pengaruh kemampuan kognitif, yang akan diketahui dari nilai rata-rata di kelas eksperimen dengan kelas kontrol. Sebelum dilaksanakan pengujian hipotesis, lebih dulu dilaksanakan pengujian normalitas guna melihat apakah data yang diperoleh terdistribusi normal ataupun tidak. Berdasarkan pada hasil perhitungan pada lampiran $\mathrm{R}$ diperoleh $\mathrm{X}^{2}$ hitung $<\mathrm{X}^{2}$ tabel baik itu pada kelas eksperimen ataupun kelas kontrol maka bisa diambil kesimpulan bahwa kedua kelas tersebut berdistribusi normal. Pengujian normalitas dilaksanakan terhadap data kemampuan awal (pre-tes) serta data kemampuan akhir (post-tes) kedua kelompok. Uji normalitas data mempergunakan pengujian Shapiro Wilk (S-W) dengan memanfaatkan program SPSS 20.0. Jika sig. Hitung $\geq 0,05$ (sig.acuan), sehingga distribusi skornya normal, begitu juga kebalikannya. Hasil perhitungan yang didapat bisa diketahui dalam Tabel 1.

Tabel 1. Hasil Uji Normalitas

\begin{tabular}{cccc}
\hline Data & $\begin{array}{c}\text { Sig } \\
\text { Acuan }\end{array}$ & $\begin{array}{c}\text { Signifikansi } \\
(\text { sig })\end{array}$ & Kesimpulan \\
\hline $\begin{array}{c}\text { Pre-Test } \\
(\mathrm{KE})\end{array}$ & 0,05 & 0,197 & Normal \\
\hline $\begin{array}{c}\text { Pre-Test } \\
(\mathrm{KK})\end{array}$ & 0,05 & 0,381 & Normal \\
\hline $\begin{array}{c}\text { Post-Test } \\
(\mathrm{KE})\end{array}$ & 0,05 & 0,121 & Normal \\
\hline Post-Test & 0,05 & 0,181 & Normal \\
\hline
\end{tabular}


Dari ringkasan Tabel 1, hasil pengujian normalitas tersebut didapatkan bahwa tiap data sig > sig acuan 5\%. Hasil demikian memperlihatkan bahwa keseluruhan data variabel penelitian terdistribusi normal.

Sedangkan untuk analisis data pengujian homogenitas dipakai guna melihat distribusi variabel homogen ataupun tidak. Pengujian homogenitas dilaksanakan melalui mempergunakan uji F. Pada penelitian kali ini, pengujian homogenitas dilaksanakan pada data pre-test serta post-test baik pada kelompok eksperimen ataupun kelompok kontrol. Adapun ringkasan hasil output SPSS diperlihatkan dalam Tabel 2 berikut.

Tabel 2. Rangkuman Hasil Uji Homogenitas

\begin{tabular}{ccccc}
\hline Data & $\mathrm{F}_{\text {hit }}$ & $\mathrm{F}_{\text {tabe }}$ & $\mathrm{df1} ; \mathrm{df2}$ & Kesimpulan \\
& ung & । & & \\
\hline Pre- & 0,5 & 3,99 & $1 ; 66$ & Homogen \\
Test & 60 & & & \\
\hline Post- & 3,1 & 3,99 & $1 ; 66$ & Homogen \\
Test & 00 & & & \\
\hline
\end{tabular}

Mengacu pada Tabel 2 itu memperlihatkan bahwa hasil pengujian homogenitas yang dilaksanakan melalui uji-F memperlihatkan data Pretest $F_{\text {hitung }}$ $(0,560)<F_{\text {tabel }}(3,99)$ dengan $d f 1=1$ dan $d f 2=66$ dari taraf signifikansi $5 \%$, sehingga data itu homogen. Data Posttest $F_{\text {hitung }}(3.100)<$ Ftabel $(3,99)$ dengan $d f 1$ $=1$ dan $d f 2=66$ dari taraf signifikansi $5 \%$, sehingga data itu homogen.

Selanjutnya dilakukan pengujian hipotesis dengan melihat rata-rata nilai pretest serta posttest pada kelas eksperimen dengan kelas kontrol. Sesudah dilaksanakan uji homogenitas dengan uji normalitas, data uji penelitian memiliki penyebaran yang homogen dan normal, sehingga dilanjutkan dengan mencari selisih antara nilai posttest dan pretest, sehingga dapat dilakukan pengujian hipotesis dengan test-t, Rangkuman analisis uji hipotesis bisa diketahui dalam Tabel 3 yaitu. 
Tabel 3. Rangkuman Analisis Uji Hipotesis

\begin{tabular}{llllll}
\hline Data & $\mathrm{T}_{\text {Hitung }}$ & $\mathrm{T}_{\text {Tabel }}$ & Df & $\begin{array}{l}\text { Sig. } \\
\text { tailed })\end{array}$ & (2- \\
& & & & Kesimpulan \\
\hline Pre & - & 1,996 & 66 & 0,624 & Tidak \\
test & 0.492 & & & & signifikan \\
\hline Post & 3,092 & 1,996 & 66 & 0,003 & Signifikan \\
test & & & & & \\
\hline
\end{tabular}

Berdasarkan Tabel 3 hasil pengujian menggunakan bantuan SPSS 21. bahwa uji-t bisa diterangkan bahwa hasil kemampuan awal (pre-test) yaitu thitung $(0,492)<$ $t_{\text {tabel }}(1,996)$ dan $\mathrm{df}=66$ dari taraf signifikansi $5 \%$, artinya diantara kelas kontrol dan kelas eksperimen perbedaannya tidak signifikan. Hasil demikian memperlihatkan potensi siswa sebelum dibagikan perlakuan dapat diutarakan serupa diantara kelas eksperimen dan kelas kontrol. Hasil uji-t sesudah dibagikan perlakuan (post-test) ialah $t_{\text {hitung }}>t_{\text {tabel }}(3,092>1,996)$ maksudnya antara kelas eksperimen dan kelas kontrol perbedaannya signifikan. Hasil demikian memperlihatkan potensi peserta didik sesudah dibagikan perlakuan berbeda, yaitu kelas eksperimen mempergunakan Blended Learning dengan basis Schoology dengan kelas kontrol tanpa Blended Learning dengan basis Schoology dalam proses belajar mengajar. Nampak potensi peserta didik kelas eksperimen lebih tinggi dibanding kelas kontrol diperlihatkan dari terdapatnya perbedaan nilai rata-rata peserta didik. Mengacu pada perhitungan uji-t bisa diambil kesimpulan bahwa pembelajaran mempergunakan Blended Learning dengan basis Schoology bisa menaikan hasil belajar peserta didik. Sehingga hipotesis yang menjelaskan "Pengaruh Penggunaan Blended Learning Berbasis Schoology Terhadap Hasil Belajar Peserta Didik pada Materi Kesetimbangan Ion dan pH Larutan Garam", diterima.

Jika dilihat dari nilai pretest serta posttest kelas eksperimen dan kontrol, sesudah dilaksanakan pretest pada kedua sampel, rata-rata nilai pretest kelas eksperimen dengan kelas kontrol masih tergolong rendah, yang mana rata-rata nilai pretest kelas eksperimen sejumlah 40.61 serta kelas kontrol sejumlah 41,71. Lalu sesudah kelas eksperimen dibagikan perlakuan mempergunakan Blended Learning dengan basis Schoology dan di kelas kontrol dengan pendekatan scientific tidak menggunakan Blended Learning Berbasis Schoology maka dilakukan posttest 
mempunyai tujuan guna melihat taraf penguasaan peserta didik dari materi yang sudah diberikan guru. Rata-rata nilai posttest kelas ekseprimen lebih tinggi daripada kelas kontrol, dimana rata-rata nilai posttest kelas eksperimen sejumlah 78,79 serta kelas kontrol sejumlah 70,86 bisa diketahui dalam Gambar 4 .

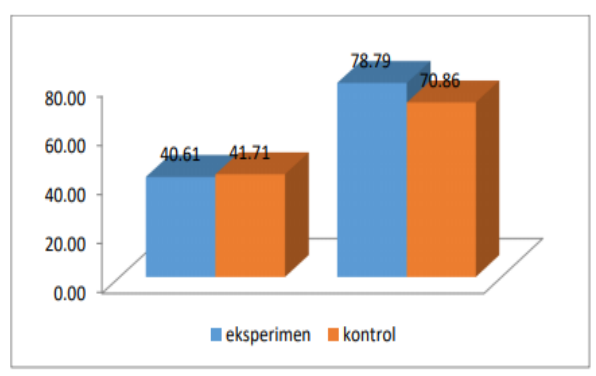

Gambar 4. Diagram Perbandingan Nilai Pretest dan Posttest

Gambar 4 tersebut menunjukkan bahwa hasil belajar kelas eksperimen yang mempergunakan blended learning berbasis schoology terhadap pokok bahasan kesetimbangan ion dan $\mathrm{pH}$ larutan garam lebih baik. Hal ini dikarenakan kelas eksperimen semua siswa terlibat aktif dan tetap semangat dalam proses belajar mengajar berlangsung, maka memudakan peserta didik menerima materi yang diajarkan dan berdampak pada nilai posttest siswa di kelas eksperimen yang lebih tinggi dari pada kelas kontrol yakni sejumlah $78,79 \%$ sebaliknya nilai kelas kontrol sejumlah $70,86 \%$. Selain hal tersebut disebabkan blended learning berbasis schoology membantu siswa saat mengalami kesukaran pada materi kimia yang sifatnya rumit, diantaranya yakni materi kesetimbangan ion dan $\mathrm{pH}$ larutan garam.

Dengan membuat pelajaran yang disusun visualisasi ke dalam bentuk gambar dan animasi lebih berarti serta menarik, memudahkan diterima dan dimengerti sehingga mampu menaikkan hasil belajar. Hal demikian selaras dari teori yang dikemukakan oleh Wicaksono yang memaparkan bahwa e-learning ialah suatu pendekatan pada proses belajar mengajar yang mampu menaikkan hasil (Wicaksono, 2016). Pada kelas kontrol dalam proses pembelajaran materi kesetimbangan ion dan $\mathrm{pH}$ larutan garam hanya menggunakan pendekatan scientific tidak menggunakan blended learning berbasis schoology, sehingga tidak semua siswa yang bersemangat dalam belajar dan siswa juga kurang memperhatikan materi yang dipelajari akibatnya materi yang diperoleh oleh siswa kurang maksimal yang dapat menyebabkan kemampuan kognitif siswa berkurang sehingga 
berdampak pada nilai posttest kelas kontrol lebih rendah dibanding kelas eksperimen. Dimana nilai yang didapatkan terhadap kelas kontrol menunjukkan perbedaan yang signifikan dari nilai yang didapat oleh kelas eksperimen.

Hasil penelitian ini selaras dengan penelitian oleh Auliyah Dzakiyyah, dkk, pada jurnal Lentera Pendidikan Pusat Penelitian LPPM UM METRO (Dzakiyyah et al., 2018). Dalam penelitian ini dapat disimpulkan bahwa penggunaan E-Learning berbasis Schoology melalui blended learning bisa menaikkan hasil belajar kognitif siswa dari hasil $\mathrm{N}$-gain sebesar 0,65. Kemudian penelitian yang dilakukan oleh Muh Yusuf Hidayat, dkk, dalam jurnal Pendidikan Fisika (Hidayat \& Andira, 2019). Penelitian ini menyatakan bahwa model pembelajaran hybrid learning dengan basis schoology lebih efektif hasil hasil pembelajaran siswa. Hasil penelitian memperlihatkan bahwa kelas eksperimen dikategorikan tinggi dari nila rata-rata siswa yaitu sejumlah 86,17 sebaliknya kelas kontrol tergolong sedang dari nilai ratarata siswa yaitu sejumlah 78,06 . Sehingga, mengacu pada hasil analisis yang didapat bisa diambil kesimpulan bahwa belajar mengajar yang diterapkan melalui penggunaan blended learning lewat mempergunakan media schoology pada hasil belajar siswa dalam kesetimbangan ion dan $\mathrm{pH}$ larutan garam kelas XI IPA SMAN 1 Tapung Hilir memberikan pengaruh dari perlakuan (KP) sebesar $5 \%$. Hasil belajar peserta didik yang dihasilkan di kelas eksperimen dibanding pada pembelajaran yang diterapkan dengan pembelajaran scientific.

\section{Kesimpulan}

Sesuai hasil penelitian sehingga bisa diambil kesimpulan bahwa penggunaan blended learning berbasis schoology dapat meningkatkan hasil belajar siswa pada pokok bahasan kesetimbangan ion dan $\mathrm{pH}$ larutan garam. Hal demikian bisa diketahui dari nilai hasil thitung $>$ tabel 3,092 $>1,996$ serta nilai sig $<0,05$ dengan demikian $\mathrm{H}_{\mathrm{o}}$ ditolak.

\section{Daftar Referensi}

Chang, R. (2004). Kimia Dasar: Konsep-Konsep Inti (Ke-3). Erlangga.

Dzakiyyah, A., Widowati, H., \& Achyani. (2018). Pengembangan e-learning berbasis schoology melalui blended learning sebagai sumber pembelajaran untuk meningkatkan hasil belajar kognitif siswa kelas $\mathrm{x}$ sma gajah mada bandar lampung. Lentera Pendidikan Pusat Penelitian LPPM UM Metro, 3(2), 263-275.

Hidayat, M. Y., \& Andira, A. (2019). Pengaruh Model Pembelajaran Hybrid Learning Berbantuan Media Schoology Terhadap Hasil Belajar Peserta Didik Kelas XI 
VOL 3 NO 1 BULAN 4 TAHUN 2021

DOI 10.25299/jrec.2021.vol3(1).6649

MIA MAN Pangkep. Jurnal Pendidikan Fisika, 7(2), 140-148. http://journal.uinalauddin.ac.id/indeks.php/PendidikanFisika

KARTIKA MURNI, C. (2016). Pengaruh E-Learning Berbasis Schoology Terhadap Peningkatan Hasil Belajar Siswa Dalam Materi Perangkat Keras Jaringan Kelas X Tkj 2 pada SMK Negeri 3 Buduran, Sidoarjo. It-Edu, 1(01), 86-90.

Siswa, M. M. (2019). Pengaruh Model Blended Learning Berbantuan. 1(2), 103-116. Sugiyono. (2011). Metode Penelitian Pendidkan Pendekatan Kuantitatif, Kualitatif, dan $R \& D$. Alfabeta.

Suharsimi. (2010). Prosedur Penelitian. Erlangga.

Wicaksono, R. (2016). Computer Supported Collaborative Learning. Seribu bintang. 